\title{
Disposable No Longer: The Spleen Holds a Reservoir of Stem Cells
}

Denise L Faustman ${ }^{1,2 *}$, Claudia Giesecke ${ }^{5}$, Miriam Davis ${ }^{2}$, Willem M Kühtreiber ${ }^{1,2}$, Simon D Tran ${ }^{3}$, Thomas Dörner ${ }^{5}$ and Eric J Ley

${ }^{1}$ Harvard Medical School, Boston MA, USA

2Immunobiology Laboratory, Massachusetts General Hospital, Boston MA, USA

${ }^{3}$ Faculty of Dentistry, McGill University, Montreal, Canada

${ }^{4}$ Department of Surgery, Cedars-Sinai Medical Center, Los Angeles CA, USA

${ }^{5}$ Department of Medicine and Rheumatology, Charity Hospital, Berlin, Germany

\begin{abstract}
Regenerative medicine is coming to recognize the value of a stem cell population that is unique to the spleen. This splenic stem cell population can robustly facilitate adult end organ regeneration and it expresses a key embryonic transcription factor, Hox11, which regulates organogenesis in diverse vertebrate species. This review article discusses the identification of this Hox11 stem cell population for its therapeutic potential in the pancreas, salivary glands, heart, bone and cranial neurons for organ regeneration. It also discusses the deleterious effects of Hox 11 stem cells in cancer, in which malignant cells revert to a Hox11 phenotype, and in certain forms of autoimmunity, in which Hox11 lineages of cells may contribute to abnormal development of end organs.
\end{abstract}

Keywords: Spleen; Hox11; Tlx1; Splenectomy; Splenic stem cells; Islet regeneration; Bone regeneration; CNS regeneration; Aorta-gonadmesonephros; Paraaortic splanchnopleura; Salivary gland regeneration; Pancreatic islet regeneration; Cardiac regeneration; Diabetes

\section{Introduction}

The spleen has gained ascendancy as the source of a multi-lineage stem cell population with myriad applications to regenerative medicine $[1,2]$. The stem cell population was identified more than a decade ago when a previously uncharacterized stem cell population from the spleen of normal animals was infused into non-obese diabetic (NOD) mice with type I diabetes. The donor stem cells of the spleen migrated to the host's pancreas where they could in part differentiate into functional pancreatic insulin-secreting islet cells that restored blood sugar levels to normal, as long as the stem cells were accompanied by an immune therapy that abolished the underlying autoimmunity $[3,4]$. Two lineage tracking techniques determined that the donor spleen cells differentiated into pancreatic islet cells instead of fusing with host cells. In $92 \%$ of the mice, the donor cells stayed fully functional for $>120$ days [4]. The splenic stem cells were also shown to be beneficial for indirect support (via release of growth factors), as well for endogenous regeneration [4,5]. Additional studies were to follow on the role of the spleen in assisting regeneration, at least in murine models. Studies by Swirski et al. identified a splenic reservoir of cells that were deployed to induced heart damage that also assisted in repair [6]. Why was the spleen so potent in assisting regeneration? Subsequent studies revealed that the splenic stem cells in mice expressed the embryonic transcription factor Hox11, also known as Tlx1 in the human $[1,2,7]$. The population was present in normal adult humans of all ages [7] (Figure 1), putting to rest the dogma from developmental biology that Hox11 expression ceases at birth [8]. The study also showed that Hox 11 expression in normal human adults was restricted to the spleen as opposed to bone marrow, kidney, liver, and tonsil [7].

The emergence of a splenic stem cell population as the source of pancreatic islets first helped explain puzzling clinical observations with atrophy or dysfunction of the pancreas was preceded by removal of the spleen. Splenectomy is sometimes necessary in cases of pancreatitis, thalassemia, immune thrombocytopenia, and trauma. When the distal pancreas is resected for chronic pancreatitis, the rate of insulindependent diabetes increases with splenectomy compared to spleen preservation $[9,10]$. Splenectomy for children with severe thalassemia also increases the risk of insulin-dependent diabetes [11-13]. Even more impressive is the evolving association of traumatic splenectomy and gradual onset of diabetes $[14,15]$. These studies suggest that when the diseased pancreas falls below a threshold function, stem cells from the spleen are released, without which diabetes is common. When resecting the diseased pancreas, spleen preservation is recommended specifically to reduce the rate of diabetes $[9,10]$. Similarly, trauma patients who require laparotomy with splenectomy have significantly higher blood glucose levels after long-term follow up compared to patients who require laparotomy with bowel resection [14]. Trauma patients who received or did not receive splenectomy in large case series of over 16,438 adults also show after a 3 -year period a twofold higher risk of diabetes [15]. Therefore, the pancreas after traumarelated shock also may benefit from splenic stem cells and splenic preservation is encouraged. With splenic atrophy from cystic fibrosis, spleen size is inversely related to Hemoglobin ( $\mathrm{Hb}) \mathrm{A1C}$ levels; the smaller the spleen, the higher the HbAlc [16]. The diseased pancreas in cystic fibrosis may also benefit from splenic stem cells. As the spleen atrophies, stem cell availability drops and pancreas function fails, increasing HbAlc levels. These clinical observations support the role of multi-lineage cells from the spleen as being necessary to maintain pancreas function.

\section{Developmental Biology}

The expression of Hox 11 marks splenic stem cells as being embryonic in nature. Hox 11 (also known as Tlx1 or TCL-3), initially a protein exclusive to fetal development, was first identified in adult mammals in association with cancers, including T-cell acute lymphocytic leukemia [17]. More research uncovered its fundamental role in development:

*Corresponding author: Denise L Faustman, Director, Immunobiology Laboratory, Associate Professor of Medicine, Harvard Medical School, USA, Tel: 617-7264084; Fax: 617-726-4095; E-mail: faustman@helix.mgh.harvard.edu

Received June 30, 2014; Accepted July 25, 2014; Published July 27, 2014

Citation: Faustman DL, Giesecke C, Davis M, Kühtreiber WM, Tran SD, et al. (2014) Disposable No Longer: The Spleen Holds a Reservoir of Stem Cells. J Stem Cell Res Ther 4: 219. doi:10.4172/2157-7633.1000219

Copyright: (c) 2014 Faustman DL, et al. This is an open-access article distributed under the terms of the Creative Commons Attribution License, which permits unrestricted use, distribution, and reproduction in any medium, provided the original author and source are credited. 


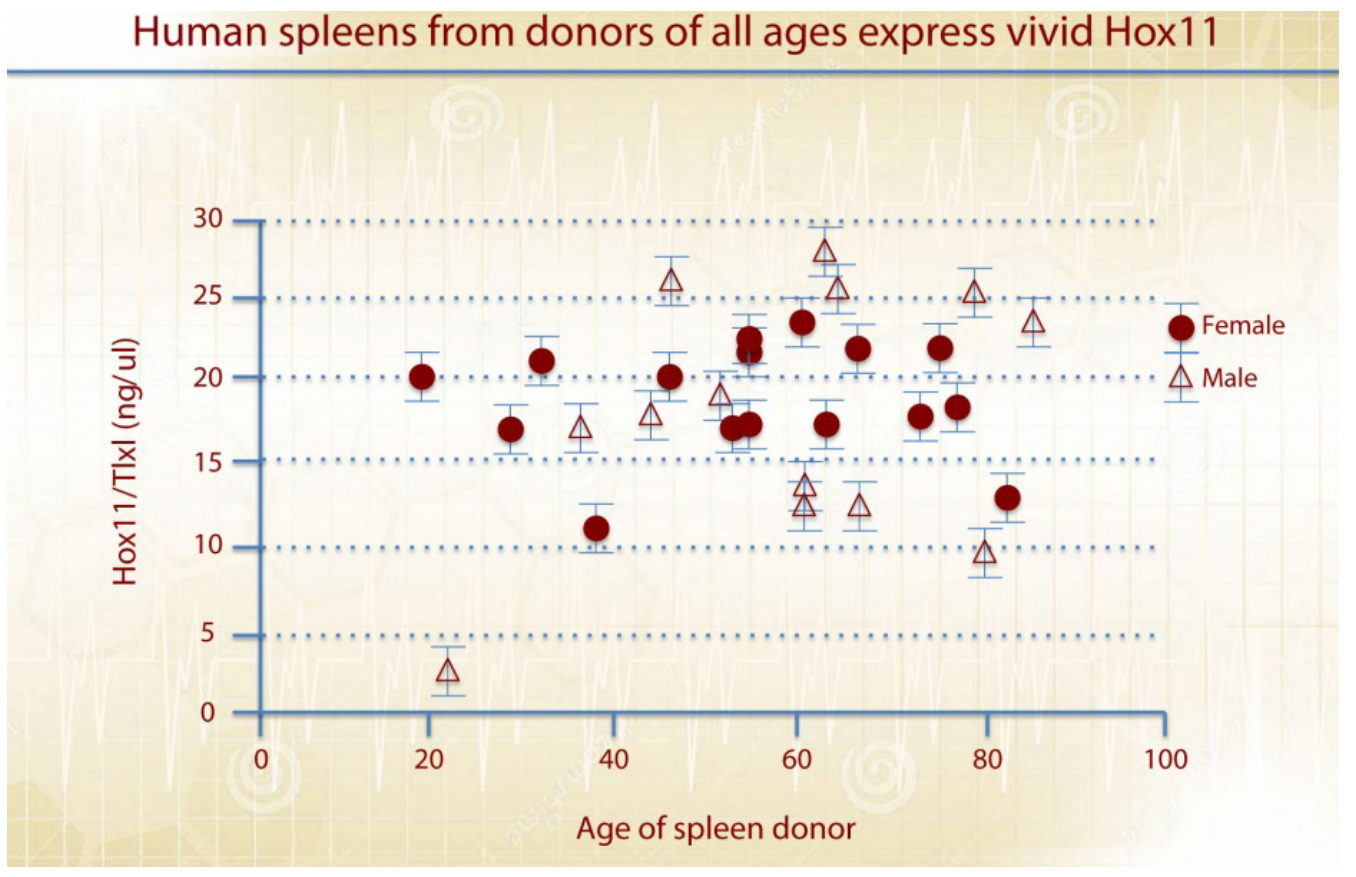

Figure 1: Adult humans of all ages still have Hox11 expressing stem cells in the spleen.

Hox11 is a transcription factor encoded by a highly conserved homeobox gene that activates a multitude of other genes responsible for cell fate and differentiation [18-20]. Hox11 also plays a dramatic role in regeneration, considering that persistent upregulation of a Hox11-like gene in newts contributes to regeneration of entire limbs and tails [21,22]. Hox 11 is obligatory for development of spleen because Hox $11^{-/}$knockout mice fail to form a spleen [23]. Hox11 is specifically expressed in the capsule and trabeculae of the spleen and the capsule appears responsible for the survival of the splenic stem cell precursors. Its absence likely leads to precursors' cell death after E12.5. The Hox11 gene is essential for cell survival during spleen development. Hox11 is expressed during embryogenesis also in a wide range of tissues other than the spleen, including brachial arches and presumptive pharynx, tongue, mandible, ear, salivary gland, hindbrain, spinal cord, and cranial ganglia, and pancreas $[8,24,25]$. In the murine species and by histologic monitoring, Hox11 expression occurs beginning E8.5 [26]. However, genetic deletion of Hox 11 does not lead to abrogation of the development of these other tissues pointing towards a highly specific and unique relationship between Hox11 and the spleen. If affected by disease, these organs and tissues might potentially benefit from Hox11 stem cells as therapy.

One key question is why these multi-lineage and unique stem cells are found in the spleen. The answer may trace their origin to a portion of the embryo known as the aorta-gonad-mesonephros (AGM), a region of the mammalian embryo that forms directly from a cluster of cells known as the para-aortic splanchnopleura (P-Sp) (Figure 2). Forming at embryonic day 10 in mice, the AGM is a band of tissue that is the first intra-embryonic site of hematopoiesis. When transplanted into neonatal mice, AGM cells show pluripotency [27]. The yolk sac, which is extra-embryonic, is the only other site of hematopoiesis at this time during development $[27,28]$. Upon further development, hematopoietic stem cells migrate to the embryonic liver and spleen where they continue to generate hematopoietic cells. It is only later, on embryonic day 15 , that the bone marrow takes over hematopoiesis.
One hypothesis is that the spleen's population of Hox11 stem cells is precursors to hematopoietic stem cells. In the absence of disease, Hox 11 stem cells during adult life are not found in the bone marrow $[1,2,4,29]$.

Interrelationships during development may explain the role of the spleen as harboring pancreatic stem cells. The spleen and the pancreas are formed around the same time during development and in close proximity, according to decades of descriptive embryology in a wide range of vertebrate species [30-32]. The spleen has a mesodermal origin, as does an embryonic portion of the pancreas, the dorsal pancreatic mesoderm. Even though the main body of the pancreas is formed from endoderm and the spleen is from mesoderm, there are interactions in terms of trophic factors released from dorsal pancreatic mesoderm [31,33]. A dramatic indication of the close relationship during development between the spleen and the pancreas comes from a knockout study in which mice that were genetically devoid of an exocrine pancreas, due to deletion of the PTF1 gene, had formed fully functional islets located in the spleen instead of the missing pancreas [34].

\section{Multi-lineage Potential of Splenic Stem Cells}

One major benefit of stem cells residing in the spleen, a nonessential organ, is that they could be harvested for their applications to regenerative medicine without severe health consequences. Besides Type 1 diabetes, splenic stem cells have therapeutic potential for diseases of other organs by virtue of their capacity to directly differentiate into specific tissues, or indirectly provide growth factors for differentiation of those tissues [4,5,35-37]. Splenic stem cells uniquely contribute directly or indirectly to regeneration of bone $[38,39]$, salivary gland $[36,40,41]$, cochlea and cranial nerve [24,25], endothelium [42], blood [4], possibly heart [6] and brain cells [43,44] (Figure 3). In one of the earliest studies, a transgenic mouse line that overexpresses IL-5 displayed ectopic bone formation in the spleen [38]. This study suggests that IL- 5 overexpression serves to mobilize osteogenic progenitors. In a related study, spleen-derived stromal cells from rats were isolated and 


\section{Hematopoiesis and Stem Cell Development}

\section{P-Sp: Paraaortic Splanchnopleural \\ AGM: Aorta-gonad- mesonephros}

Figure 2: From developmental biology it is known that murine hematopoiesis originates in the yolk sac and paraaortic splanchopleural ( $\mathrm{P}$-Sp) or aorta-gonadmesonephros (AGM) before occurring in the spleen and later in the bone marrow.

\section{Regenerative Functions Identified for Splenic Stem Cells}

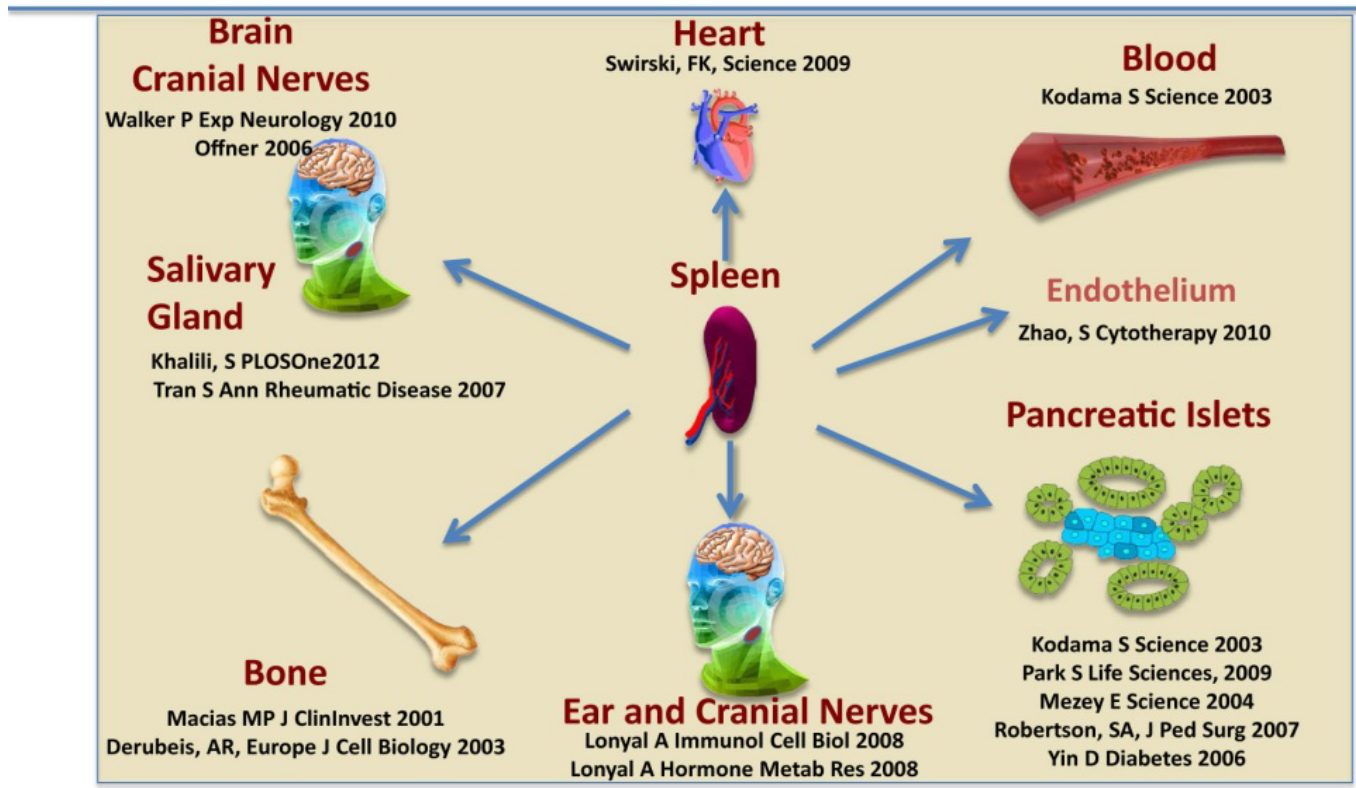

Figure 3: In adults, the splenic stem cells demonstrate the ability to assist end organ regeneration in the CNS, cranial nerves, bone, heart, blood, pancreatic islets, salivary glands and inner ear.

cultured in conditions intended to induce osteogenic differentiation, i.e., fibroblast growth factor 2 and dexamethasone [39]. After the primary cultures attained confluence, they were subjected either to an osteo-inductive medium or implanted into immuno-deficient mice. Although nothing emerged from the in vivo experiments, the cultured spleen cells managed to deposit a mineralized matrix. Further analysis established their expression of bone proteins such as osteocalcin and bone sialoprotein. The study concluded that the spleen stromal cells can differentiate into bone cells given a permissive microenvironment.

In a test of salivary gland regeneration, donor splenocytes were 
infused into NOD mice, which not only display type I diabetes, but also a Sjogren's-like disease, which is marked by reduced salivary flow as a result of immunological attack on the salivary gland [40]. All NOD mice receiving the splenocytes, along with an immunotherapy that destroyed autoreactive $\mathrm{T}$ cells, revealed complete recovery of salivary flow. The recovery was achieved by a combination of rescue of salivary epithelial cells, as well as differentiation of splenocytes into salivary epithelial cells, according to fluorescence in situ hybridization and immunohistochemical staining. The animals also became normoglycemic due to the treatment's beneficial effects on the pancreas [36].

NOD mice also exhibit profound structural abnormalities in the cochlea that produce hearing loss. Deafness is present at birth in the NOD mouse, occurring before onset of type I diabetes and Sjogren'slike syndrome disease [24,25]. Donor splenocytes given to NOD mice, along with an immunotherapy that abolishes the underlying autoimmunity, resulted in two of eight animals showing complete and permanent recovery in hearing and two others exhibiting some minor improvement as demonstrated by lower thresholds in the auditory brainstem response (a lower threshold is indicative of better hearing). When examined histologically, the two successfully treated mice showed a normal spiral ligament with a full, or nearly full, population of cells in the lower third turn and lower second turn of the cochlea. Additionally, the morphology showed that the organ of Corti was restored, carrying a full population of hair cells and apparent restoration of the tunnel of Corti in the lower second and third turns. This murine study concluded that splenic stem cells, combined with immunotherapy, can directly or indirectly regenerate the cochlea and VIII cranial nerve in order to reverse or mitigate hearing loss.

The implications of splenic stem cells for systemic autoimmune diseases, such as Sjögren's syndrome, are less clear. Involvement of splenic stem cells in the development of adaptive immunity has been demonstrated. For $\mathrm{T}$ cells, it has been shown [45] that thymic and intestinal $\mathrm{T}$ cell precursors reside in the spleen, however, these cells were not essential for development of $\mathrm{T}$ cell subsets since transplanted bone marrow HSC could substitute completely. In contrast, the spleen is the essential organ for B1a B cell generation [46] completely independent of bone marrow B cell subsets. B1a B cells originate from lineage negative precursors located in the spleen already from birth on [47] and play a crucial role in producing the protective film of $\operatorname{sIgA}$ on the gut luminal site as part of natural antibodies. Recent studies in HOX11 knockout mice [48] provide evidence that B1a B cells in contrast to B1b and B2 B cells are responsible for the provision of sIgA on mucosal surfaces. Since Sjögren's syndrome is mainly affecting excretory glands at mucosal surfaces, there is a possibility of impaired $\mathrm{B} 1 \mathrm{a} \mathrm{B}$ cell functions related to splenic abnormalities. However, studies in humans are inconclusive about the existence of a human B1 B cell population [48-50] and lack deeper insight in HOX11 and IgA abnormalities in patients with Sjögren's.

Nevertheless, the spleen plays an important role in B cell differentiation, especially for full maturation of immature transitional $\mathrm{B}$ cells into naïve $\mathrm{B}$ cells after leaving the bone marrow and again prior and presumably after antigen encounter. The latter maturation step is unique to splenic function since splenectomy results in accumulation of naïve B cells and substantial reductions of memory B cells [51-54]. Notably, patients with Sjögren's syndrome without splenectomy show a similar peripheral B cell distribution with predominant naïve and substantially reduced memory $B$ cells $[55,56]$ as splenectomized individuals. This is in contrast to the increase of memory B cells with reduced CD27- naive B cells in systemic lupus erythematosus (SLE) [57]. Thus, splenic stem cells could possibly complete by a second maturation imprinting full $\mathrm{B}$ cell development which might be impaired under the condition of Sjögren's.

Splenic cells' contribution to heart regeneration was demonstrated in rodents by Swirski et al. [6]. These investigators splenectomized a host animal and transplanted a donor spleen into the host. They then surgically induced ischemia of the myocardium. They showed that undifferentiated splenic monocytes exited the spleen en masse, and accumulated in the heart where they contributed to wound healing. The mechanism of heart healing was not investigated; it could have benefited the host by both indirect and direct mechanisms-by splenocyte secretion of local growth factors or by direct differentiation. This study was the first to show directly that the cells migrated from the spleen to the heart.

In a separate study, Offner et al. [58] found that induction of stroke not only affects the brain but also the spleen. After stroke induction, the study uncovered a shrinkage of the spleen from rampant cell death $(90 \%$ reduction in cells), yet an increase in T regulatory cells and striking rise in circulating $\mathrm{CD} 11 \mathrm{~b}+$ macrophages/monocytes. The study did not specifically examine the role of the Treg cells and macrophages in ameliorating the impact of the stroke. The dramatic shrinkage of the spleen after trauma or severe injury is not only a trait of induced stroke or brain injury. In the spontaneous NOD mouse model of autoimmune diabetes and Sjogren's syndrome, the spleen dramatically shrinks as the disease progresses (Figure 4). This dramatic spleen shrinkage exclusively occurs in only NOD mice that progress to diabetes. There is no shrinkage of the spleen in an NOD mouse that is not diseased. Typically about $60-80 \%$ of NOD mice express disease, so the spleen response is to peripheral injury.

Studying Type II diabetes, Park et al. [35] subjected female rats to 90\% pancreatectomy and then one of three conditions: splenectomy, splenectomy with injection of male splenocytes, or no splenectomy. The rats were then fed a high fat diet for five weeks, at which point insulin secretion was assessed, as was pancreatic $\beta$ islet-cell mass. During oral glucose tolerance testing, splenectomy increased serum glucose levels over the other two conditions. Nonsplenectomized rats had greater $\beta$-cell replication and more newly synthesized $\beta$-islets than other groups. The investigators did not determine whether the newly synthesized $\beta$-islets represented direct differentiation of splenic stem cells and/or maturation of pancreatic precursor cells induced by growth factors secreted from splenic stem cells [37]. Other investigators have chosen to expand splenic precursors in vitro to see if induction of insulin secreting cells could be observed. Using stem cells of spleen from the quail, Roberston et al. co-cultured the stem cells with chick pancreatic epithelium, insulin-producing cells could be grown and expanded [37]. Of course for clinical purposes direct in vivo differentiation, or in vivo assisted regeneration or in vitro expansion prior to transplantation are merely details that are not relevant and one would hope that all methods of regeneration assistance are active. Nevertheless, whether the splenic stem cells play a direct or indirect role does not negate their clinical benefit.

\section{Abnormal Splenic Stem Cell Development may Contribute to Cancer}

The spleen's stem cells are not of lymphoid origin because they lack the more differentiated lymphoid marker CD45. The CD45 stem cells of the spleen were compared with the spleen's more abundant population of $\mathrm{CD} 45^{+}$cells using state-of-the-art proteomics and in vivo testing [59] (Figure 5). The CD45 cells were found to have 809 unique 
Citation: Faustman DL, Giesecke C, Davis M, Kühtreiber WM, Tran SD, et al. (2014) Disposable No Longer: The Spleen Holds a Reservoir of Stem Cells. J Stem Cell Res Ther 4: 219. doi:10.4172/2157-7633.1000219

\section{Spleen shrinks in diabetic NOD}

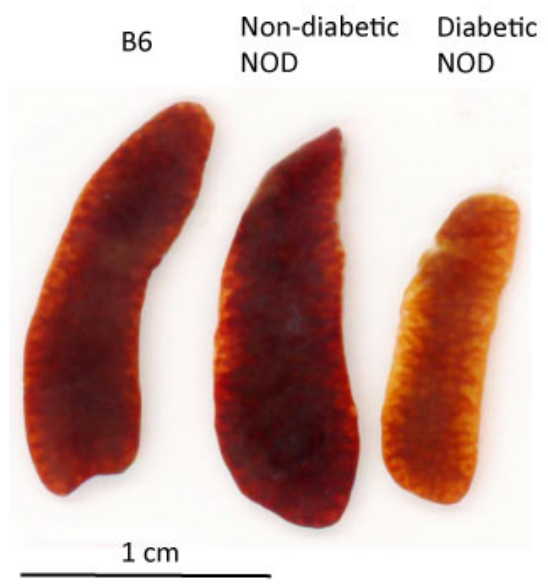

$\begin{array}{ll}\text { B6 } & 81.4 \mathrm{mg} \\ \text { Non-diabetic NOD } & 89.1 \mathrm{mg} \\ \text { Diabetic NOD } & 38.2 \mathrm{mg}\end{array}$

Figure 4: Dramatic reduction in size of the spleen with new onset type 1 diabetes in an NOD mouse. Left spleen is from a B6 control mouse, the middle spleen is from a non-diabetic NOD litter mate to the diabetic mouse (right spleen). The B6 spleen weight was 81.4 mgs, the non-diabetic NOD spleen was $89.1 \mathrm{mgs}$ and the diabetic NOD mouse spleen was 38.2 mgs. The normal female B6 spleen at $15-20$ weeks of age weights $83.4+/-2.9$ ( $n=32$ ). A shrunken NOD spleen with diabetes is uniformly observed with hyperglycemia in NOD mice ( $n=20$ mice). The NOD spleen from female mice that do not express diabetes are consistently of a normal size ( $n=17$ mice)

\section{Splenic proteins of CD45+ versus CD45-Hox11 Stem Cells}

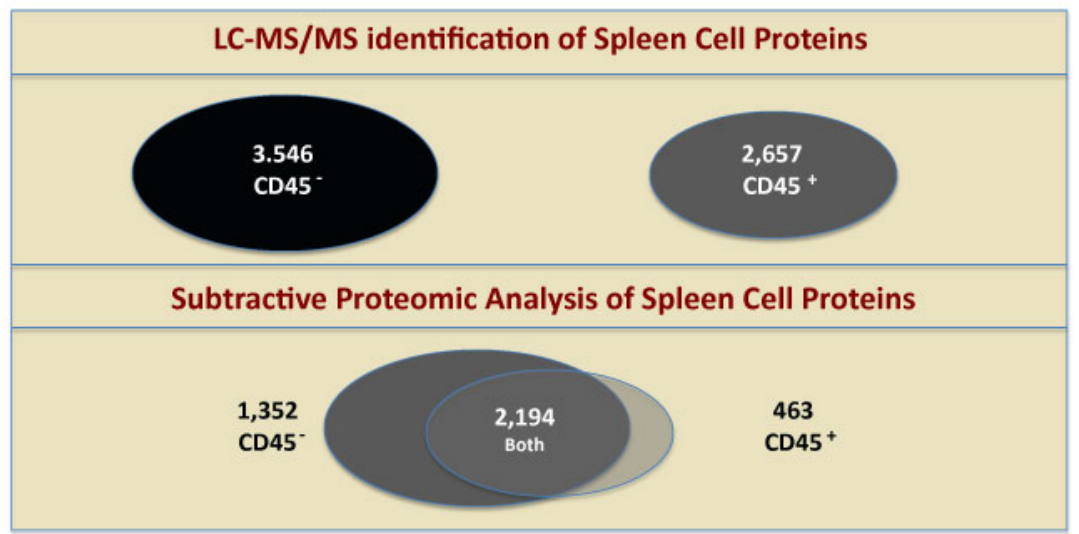

Figure 5: Proteomics demonstrates the unique signature of proteins expressed only by splenic stem cells (CD45-Hox11+), overlapping proteins or unique proteins of the mature CD45+ splenic cells. As is common for stem cells, the repertoire of unique proteins is more diverse than fully mature cells.

proteins. Among them were OCT3/4, SOX2, KLF4, c-MYC, NANOG, which are transcription factors expressed in embryonic stem cells (ES) and induced pluripotent stem cells (iPS) [60]. Research reveals that, under certain conditions, this set of transcription factors is sufficient to transform a differentiated somatic cell into a whole embryo [61]. Other unique proteins were Hox11, Gli3, Wnt2, and Adam12, all of which are transcription factors indicative of ES. Furthermore, other proteins unique to $\mathrm{CD} 45^{-}$splenic cells are involved in signal transduction pathways during normal fetal development-WNT2, NOTCH3, PTCH, and GLI3 - which are essential to the Wnt, Notch, and Sonic Hedgehog signaling pathways. These pathways also contribute to stem cell function, and, when dysregulated, they participate in cancer cell progression [62]. The study also looked at splenic stem cells' capacity for malignant transformation by comparing the 809 unique proteins with 20 signature proteins of Hox $11+$ Acute T- cell lymphoblastic leukemia. Splenic stem cells possess 10 of the 20 signature proteins, but not six proteins that are known markers of cancer: DHFR, ERCC1, HPRT1, LAP18, TDT and UNG. The overlapping proteins were DNA replication factors and DNA polymerases. The study concluded that splenic stem cells have low carcinogenic potential and possess many proteins in common with embryonic stem cells. The study suggests that splenic stem cells are less lineage-committed than bone marrow stem 
cells, which is consistent with the embryonic origins of the cells. It has been proposed that for cancers of Hox 11 origins, a splenectomy could eliminate the cancer stem cell origins [7].

The presence of Hox11-expressing cells is not always beneficial. Patients with Hox11 expressing acute lymphocytic leukemia might be candidates for splenectomy [7]. The rationale for splenectomy is that the cancer stem cells reside there, and that, according to the stem cell hypothesis of cancer, it is the rare stem cells rather than the cancer cells that are responsible for onset, perpetuation, and recurrence of human cancers. The most robust support of the cancer stem cell hypothesis comes from a study showing that only a small percentage of cells from human acute myelogenous leukemia, when transplanted to mice, are capable of sustaining tumor growth [63].

\section{Abnormal Splenic Stem Cells Development may Contribute to End Organ Failures in Autoimmunity}

Hox11 stem cells may be defective in certain forms of autoimmunity. One study looked at whether developmental defects contribute to autoimmunity $[24,25]$. It was prompted by puzzling overlaps between type I diabetes and Sjogren's syndrome. Many patients have co-occurring conditions and are beset by hearing loss and tongue abnormalities. Hearing loss and tongue abnormalities had been viewed as a result of autoimmune attack but lymphoid infiltrates were never observed thus that explanation could account for the fact that the abnormalities preceded the onset of both conditions. The study showed that Hox11-derived organs-pancreas, salivary gland, tongues and cranial nerves/cochlea-showed various structural or functional abnormalities suggestive of developmental defects. The study concluded that developmental lineage contributes to autoimmunity and predicts which target organs may be abnormal, whether structurally or functionally.

Although the literature often publishes more articles on the therapeutic effectiveness of bone marrow stem cells, some transplantation studies have performed direct comparisons of the two cell populations in controlled experiments. A head-to-head comparison of bone marrow versus spleen stem cells in treating salivary gland dysfunction in Sjogren's-like disease was conducted [64]. The bone marrow and spleen cellular therapies were given along with an immunotherapy to halt the progression of underlying autoimmunity. Spleen cell therapy performed as well as bone marrow therapy when given at the advanced phase of Sjogren's-like disease syndrome, whereas it performed better-in terms of salivary flow rate-when given at the initial phase of disease, suggesting that spleen cells have greater longevity. Both cellular therapies lowered TNF, TGF $\beta 1, T$ and B cells, while raising EGF and T regulatory cells. Neither of the cellular therapies was found to have differentiated into salivary gland cells, suggesting that their mode of action was to secrete growth factors to regenerate endogenous cells; however, in future studies the investigators plan to analyze tissue at earlier intervals post-transplant.

\section{Conclusions}

Hox11-expressing splenic stem cells are multi-lineage cells with wide-ranging applications as cellular therapies to correct diseaserelated defects. Not only have these stem cells been shown to reverse type I diabetes, they also have been shown to ameliorate salivary gland dysfunction, cochlear dysfunction, blood and injury to heart and brain cells. Proteomics reveals that these stem cells resemble embryonic stem cells, especially by virtue of expressing key transcription factors. Spontaneous abnormalities of splenic stem cells have been identified in select forms of cancer with Hox 11 origins and in at least one model of autoimmunity where the abnormal target organs are of Hox 11 origin. Because of their low likelihood of transformation, this remarkable population of stem cells is gaining momentum as a more stable alternative to embryonic stem cells for tissues in which Hox11 is expressed during development.

\section{Acknowledgement}

D.L.F. and W.M.K. are supported by The lacocca Foundation.

\section{References}

1. Kodama S, Davis M, Faustman DL (2005) Diabetes and stem cell researchers turn to the lowly spleen. Sci Aging Knowledge Environ 2005: pe2. [PubMed]

2. Kodama S, Davis M, Faustman DL (2005) Regenerative medicine: a radical reappraisal of the spleen. Trends Mol Med 11: 271-276. [PubMed]

3. Ryu S, Kodama S, Ryu K, Schoenfeld DA, Faustman DL (2001) Reversal of established autoimmune diabetes by restoration of endogenous beta cell function. J Clin Invest 108: 63-72. [PubMed]

4. Kodama S, Kuhtreiber W, Fujimura S, Dale EA, Faustman DL (2003) Islet regeneration during the reversal of autoimmune diabetes in NOD mice. Science 302: 1223-1227. [PubMed]

5. Yin D, Tao J, Lee DD, Shen J, Hara M, et al. (2006) Recovery of islet beta-cel function in streptozotocin- induced diabetic mice: an indirect role for the spleen Diabetes 55: 3256-63. [PubMed]

6. Swirski FK, Nahrendorf M, Etzrodt M, Wildgruber M, Cortez-Retamozo V, et al (2009) Identification of splenic reservoir monocytes and their deployment to inflammatory sites. Science 325: 612-616. [PubMed]

7. Dieguez-Acuna FJ, Gygi SP, Davis M, Faustman DL (2007) Splenectomy: a new treatment option for ALL tumors expressing Hox-11 and a means to test the stem cell hypothesis of cancer in humans. Nature Leukemia 21: 21922194.

8. Dear TN, Colledge WH, Carlton MB, Lavenir I, Larson T, et al. (1995) The Hox11 gene is essential for cell survival during spleen development. Development 121: 2909-2915. [PubMed]

9. Hutchins RR, Hart RS, Pacifico M, Bradley NJ, Williamson RC (2002) Longterm results of distal pancreatectomy for chronic pancreatitis in 90 patients. Ann Surg 236: 612-618. [PubMed]

10. Govil S, Imrie CW (1999) Value of splenic preservation during distal pancreatectomy for chronic pancreatitis. Br J Surg 86: 895-898. [PubMed]

11. Lee BW, Tan SH, Lee WK, Yap HK, Aw SE, et al. (1985) Glucose tolerance test and insulin levels in children with transfusion-dependent thalassaemia. Ann Trop Paediatr 5: 215-218. [PubMed]

12. Bannerman RM, Keusch G, Kreimer-Birnbaum M, Vance VK, Vaughan S (1967) Thalassemia intermedia, with iron overload, cardiac failure, diabetes mellitus, hypopituitarism and porphyrinuria. Am J Med 42: 476-486. [PubMed]

13. Al Hawsawi ZM, Hummaida TI, Ismail GA (2001) Splenectomy in thalassaemia major: experience at Madina Maternity and Children's Hospital, Saudi Arabia. Ann Trop Paediatr 21: 155-158. [PubMed]

14. Ley EJ, Singer MB, Clond MA, Johnson T, Bukur M, et al. (2012) Long-term effect of trauma splenectomy on blood glucose. J Surg Res 177: 152-156. [PubMed]

15. Wu SC, Fu CY, Muo CH, Chang YJ (2014) Splenectomy in trauma patients is associated with an increased risk of postoperative type II diabetes: a nationwide population-based study. Am J Surg. [PubMed]

16. Jarad NA, Sequeiros IM, Hester K, Callaway M, Williams AJ, et al. (2010) The size of the spleen by magnetic resonance imaging in patients with cystic fibrosis; with and without diabetes--a novel observational study. QJM 103: 237242. [PubMed]

17. Hatano M, Roberts CW, Minden M, Crist WM, Korsmeyer SJ (1991) Deregulation of a homeobox gene, HOX11, by the $t(10 ; 14)$ in T cell leukemia. Science 253: 79-82. [PubMed]

18. Andermann P, Weinberg ES (2001) Expression of zTIXA, a Hox11-like gene in early differentiating embryonic neurons and cranial sensory ganglia of the zebrafish embryo. Dev Dyn 222: 595-610. [PubMed] 
Citation: Faustman DL, Giesecke C, Davis M, Kühtreiber WM, Tran SD, et al. (2014) Disposable No Longer: The Spleen Holds a Reservoir of Stem Cells. J Stem Cell Res Ther 4: 219. doi:10.4172/2157-7633.1000219

19. Langenau DM, Palomero T, Kanki JP, Ferrando AA, Zhou Y, et al. (2002) Molecular cloning and developmental expression of TIX (Hox11) genes in zebrafish (Danio rerio). Mech Dev 117: 243-248. [PubMed]

20. Hashimoto K, Yokouchi Y, Yamamoto M, Kuroiwa A (1999) Distinct signaling molecules control Hoxa-11 and Hoxa-13 expression in the muscle precursor and mesenchyme of the chick limb bud. Development 126: 2771-2783. [PubMed]

21. Simon HG, Tabin CJ (1993) Analysis of Hox-4.5 and Hox-3.6 expression during newt limb regeneration: differential regulation of paralogous Hox genes suggest different roles for members of different Hox clusters. Development 117: 1397-1407. [PubMed]

22. Beauchemin M, Noiseux N, Tremblay M, Savard P (1994) Expression of Hox A11 in the limb and the regeneration blastoma of adult newt. Int J Dev Biol 38 641-649. [PubMed]

23. Roberts CW, Shutter JR, Korsmeyer SJ (1994) Hox11 controls the genesis of the spleen. Nature 368: 747-749. [PubMed]

24. Lonyai A, Kodama S, Burger D, Davis M, Faustman DL (2008) The promise of Hox $11+$ stem cells of the spleen for treating autoimmune diseases. Horm Metab Res 40: 137-146. [PubMed]

25. Lonyai A, Kodama S, Burger D, Faustman DL (2008) Fetal Hox11 expression patterns predict defective target organs: a novel link between developmental biology and autoimmunity. Immunol Cell Biol 86: 301-309. [PubMed]

26. Raju K, Tang S, Dube ID, Kamel-Reid S, Bryce DM, et al. (1993) Characterization and developmental expression of TIX-1, the murine homolog of HOX11. Mech Dev 44: 51-64. [PubMed]

27. Medvinsky AL, Samoylina NL, Muller AM, Dzierzak EA (1993) An early pre-liver intraembryonic source of CFU-S in the developing mouse. Nature 364: 64-67. [PubMed]

28. Godin IE, Garcia-Porrero JA, Coutinho A, Dieterlen-Lievre F, Marcos MA (1993) Para-aortic splanchnopleura from early mouse embryos contains B1a cell progenitors. Nature 364: 67-70. [PubMed]

29. Kodama S, Faustman DL (2004) Routes to regenerating islet cells: stem cells and other biological therapies for type 1 diabetes. Pediatr Diabetes 5: 38-44. [PubMed]

30. Thiel GA, Downey H (1921) The development of the mammalian spleen, with special reference to its hematopoietic activity. Am J Anat 28: 279-339.

31. Wessels NK, Cohen JH (1967) Early pancreas organogenesis: morphogenesis, tissue interactions and mass effects. Dev Biol 15: 237-270. [PubMed]

32. Patterson KD, Drysdale TA, Krieg PA (2000) Embryonic origins of spleen asymmetry. Development 127: 167-175. [PubMed]

33. Gosolow N, Grobstein C (1962) Epithelio-mesenchymal interaction in pancreatic morphogeneis. Dev Biol 4: 242-255. [PubMed]

34. Krapp A, Knofler M, Ledermann B, Burki K, Berney C, et al. (1998) The bHLH protein PTF1-p48 is essential for the formation of the exocrine and the correct spatial organization of the endocrine pancreas. Genes Dev 12: 3752-3763. [PubMed]

35. Park S, Hong SM, Ahn IS (2009) Can splenocytes enhance pancreatic beta-cell function and mass in $90 \%$ pancreatectomized rats fed a high fat diet? Life Sci 84: 358-363. [PubMed]

36. Mezey E (2004) Commentary: on bone marrow stem cells and openmindedness. Stem Cells Dev 13: 147-52. [PubMed]

37. Robertson SA, Rowan-Hull AM, Johnson PR (2008) The spleen--a potential source of new islets for transplantation? J Pediatr Surg 43: 274-278. [PubMed]

38. Macias MP, Fitzpatrick LA, Brenneise I, McGarry MP, Lee JJ, et al. (2001) Expression of IL-5 alters bone metabolism and induces ossification of the spleen in transgenic mice. J Clin Invest 107: 949-959. [PubMed]

39. Derubeis AR, Mastrogiacomo M, Cancedda R, Quarto R (2003) Osteogenic potential of rat spleen stromal cells. Eur J Cell Biol 82: 175-181. [PubMed]

40. Tran SD, Kodama S, Lodde BM, Szalayova I, Key S, et al. (2007) Reversa of Sjogren's-like syndrome in non-obese diabetic mice. Ann Rheum Dis 66: 812-814. [PubMed]

41. Khalili S, Liu Y, Kornete M, Roescher N, Kodama S, et al. (2012) Mesenchyma stromal cells improve salivary function and reduce lymphocytic infiltrates in mice with Sjogren's-like disease. PLoS One 7: e38615. [PubMed]
42. Zhao X, Wu N, Huang L (2010) Endothelial progenitor cells and spleen: new insights in regeneration medicine. Cytotherapy 12: 7-16. [PubMed]

43. Offner H, Subramanian S, Parker SM, Wang C, Afentoulis ME, et al. (2006) Splenic atrophy in experimental stroke is accompanied by increased regulatory T cells and circulating macrophages. J Immunol 176: 6523-6531. [PubMed]

44. Walker PA, Shah SK, Jimenez F, Gerber MH, Xue H, et al. (2010) Intravenous multipotent adult progenitor cell therapy for traumatic brain injury: preserving the blood brain barrier via an interaction with splenocytes. Exp Neurol 225 341-352. [PubMed]

45. Hamad M, Whetsell M, Klein JR (1995) T cell precursors in the spleen gives rise to complex $\mathrm{T}$ cell repertoires in the thymus and the intestine. J Immunol 155: 2866-2876. [PubMed]

46. Wardemann H, Boehm T, Dear N, Carsetti R (2002) B-1a B cells that link the innate and adaptive immune responses are lacking in the absence of the spleen. J Exp Med 195: 771-780. [PubMed]

47. Rosado MM, Aranburu A, Capolunghi F, Giorda E, Cascioli S, et al. (2009) From the fetal liver to spleen and gut: the highway to natural antibody. Mucosal Immunol 2: 351-361. [PubMed]

48. Griffin DO, Holodick NE, Rothstein TL (2011) Human B1 cells are CD3-: A reply to "A human equivalent of mouse B-1 cells?" and "The nature of circulating CD27+CD43+ B cells". J Exp Med 208: 2566-2569. [PubMed]

49. Griffin DO, Holodick NE, Rothstein TL (2011) Human B1 cells in umbilical cord and adult peripheral blood express the novel phenotype CD20+ CD27+ CD43+ CD70. J Exp Med 208: 67-80. [PubMed]

50. Perez-Andres M, Grosserichter-Wagener C, Teodosio C, van Dongen JJ, Orfao A, et al. (2011) The nature of circulating CD27+CD43+ B cells. J Exp Med 208: 2565-2566. [PubMed]

51. Descatoire M, Weill JC, Reynaud CA, Weller S (2011) A human equivalent of mouse B-1 cells? J Exp Med 208: 2563-2564. [PubMed]

52. Kruetzmann S, Rosado MM, Weber H, Germing U, Tournilhac $O$, et al. (2003) Human immunoglobulin M memory B cells controlling Streptococcus pneumoniae infections are generated in the spleen. J Exp Med 197: 939-945.

53. Mamani-Matsuda M, Cosma A, Weller S, Faili A, Staib C, et al. (2008) The human spleen is a major reservoir for long-lived vaccinia virus-specific memory B cells. Blood 111: 4653-4659. [PubMed]

54. Martinez-Gamboa L, Mei H, Loddenkemper C, Ballmer B, Hansen A, et al. (2009) Role of the spleen in peripheral memory B-cell homeostasis in patients with autoimmune thrombocytopenia purpura. Clin Immunol 130: 199-212. [PubMed]

55. Bohnhorst JO, Thoen JE, Natvig JB, Thompson KM (2001) Significantly depressed percentage of CD27+ (memory) $B$ cells among peripheral blood $B$ cells in patients with primary Sjogren's syndrome. Scand J Immunol 54: 421. 427.

56. Hansen A, Gosemann M, Pruss A, Reiter K, Ruzickova S, et al. (2004) Abnormalities in peripheral B cell memory of patients with primary Sjogren's syndrome. Arthritis Rheum 50:1897-1908. [PubMed]

57. Wahren-Herlenius M, Dorner T (2013) Immunopathogenic mechanisms of systemic autoimmune disease. Lancet 382: 819-831. [PubMed]

58. Offner H, Subramanian S, Parker SM, Wang C, Afentoulis ME, et al. (2006) Splenic atrophy in experimental stroke is accompanied by increased regulatory T cells and circulating macrophages. J Immunol 176: 6523-6231. [PubMed]

59. Dieguez-Acuna F, Kodama S, Okubo Y, Paz AC, Gygi SP, et al. (2010) Proteomics identifies multipotent and low oncogenic risk stem cells of the spleen. Int J Biochem Cell Biol 42: 1651-1660. [PubMed]

60. Takahashi K, Yamanaka S (2006) Induction of pluripotent stem cells from mouse embryonic and adult fibroblast cultures by defined factors. Cell 126: 663-676. [PubMed]

61. Okita K, Nakagawa M, Hyenjong H, Ichisaka T, Yamanaka S (2008) Generation of mouse induced pluripotent stem cells without viral vectors. Science 322 949-953. [PubMed]

62. Blank U, Karlsson G, Karlsson S (2008) Signaling pathways governing stemcell fate. Blood 111: 492-503. [PubMed]

63. Hope KJ, Jin L, Dick JE (2004) Acute myeloid leukemia originates from a 
Citation: Faustman DL, Giesecke C, Davis M, Kühtreiber WM, Tran SD, et al. (2014) Disposable No Longer: The Spleen Holds a Reservoir of Stem Cells. J Stem Cell Res Ther 4: 219. doi:10.4172/2157-7633.1000219

Page 8 of 8

hierarchy of leukemic stem cell classes that differ in self-renewal capacity. Nat Immunol 5: 738-743. [PubMed]

64. Khalili S, Faustman DL, Liu Y, Sumita Y, Blank D, et al. (2014) Treatment for salivary gland hypofunction at both initial and advanced stages of Sjogrenlike disease: a comparative study of bone marrow therapy versus spleen cell therapy with a 1-year monitoring period. Cytotherapy 16: 412-423. [PubMed] 